\title{
The Role of Reflective Practice in Mediating Development of Pre-Service Science Teachers' Professional and Classroom Knowledge
}

\author{
Festo Kayima $^{1 *}$ \\ ${ }^{1}$ Department of Teacher Education, Norwegian University of Science and Technology, NORWAY \\ *Corresponding Author: festo.kayima@ntnu.no
}

Citation: Kayima, F. (2022). The role of reflective practice in mediating development of pre-service science teachers' professional and classroom knowledge. Interdisciplinary Journal of Environmental and Science Education, 18(1), e2262. https://doi.org/10.21601/ijese/11364

\begin{tabular}{ll}
\hline ARTICLE INFO & ABSTRACT \\
\hline Received: & $\begin{array}{l}\text { The present study explores the potential of reflective practice in supporting pre-service teachers' } \\
\text { development of professional and classroom knowledge elements. The exploration process involved pre- } \\
\text { service science teachers documenting and discussing their lived teaching experiences during school } \\
\text { practice. The overall aim was to establish the effectiveness of reflective writing in promoting a reflection } \\
\text { process with which teacher knowledge development could be mediated. From the analysis, strategically } \\
\text { Accepted: }\end{array}$ \\
21 November 2021 & $\begin{array}{l}\text { enacted reflective writing is a tool that enables a reflection process where trainees' transitions in thinking } \\
\text { about the practice of teaching are visible. Moreover, reflective writing is a potential medium tool for pre- } \\
\text { service teachers to articulate and advance their developed assertions about teaching. The importance of } \\
\text { negotiating and legitimizing trainees' emerging perspectives and constructed assertions is discussed. }\end{array}$
\end{tabular}

Keywords: reflective practice, professional \& classroom knowledge, teacher assertions, school practice, non-routine teaching situations

\section{INTRODUCTION}

The complexities involved in the teaching process as well as in learning to teach have seen a great deal of educational research spanning several decades devote to developing and establishing a knowledge base for teaching (e.g.; Abell, Rogers, Hanuscin, Lee, \& Gagnon, 2009; Ben-Peretz, 2011; Kind, 2009b; König, Bremerich-Vos, Buchholtz, \& Glutsch, 2020; Lederman \& Lederman, 2015; Loughran, Mulhall, \& Berry, 2008; Verloop, Van Driel, \& Meijer, 2001; Ünver, 2014). By the mid-1970s, a consensus among several educators and researchers at the time was that being an expert teacher in the subject matter did not directly translate into being an expert teacher of that subject matter (Bucat, 2005; Kind, 2009b; Lederman \& Lederman, 2015). It was argued that, in addition to being an expert in the subject matter, a different kind of knowledge was needed that informs and results in transformation of subject matter into instruction, including an understanding of the relationship between the taught subject matter and students' knowledge and ideas (Shulman, 1986). This understanding implied that the teachers' knowledge base for teaching comprised both specialist subject knowledge and a set of knowledge elements and competences needed for use in the process of teaching (Abell et al., 2009; Ball \& Cohen, 1999; Barnett \& Hodson, 2001; Bucat, 2005; Grossman \& Richert, 1988; Kind, 2009a, 2009b; König et al., 2020; Shulman, 1986, 1987).

Since the mid-1970s, characterizing a set of knowledge elements and competences for teachers by educational researchers has been ongoing. One wellknown teacher knowledge category system was proposed by the Lee Shulman (1986), comprising three categories of "content knowledge for teachers, (i) subject -matter content knowledge, (ii) subject-matter pedagogical knowledge - "ways of representing and formulating the subject that make it comprehensible to others", and (iii) curricular knowledge - materials available to use in the classroom, such as textbooks (p. 13). Shulman later in 1987, refined and expanded the categories into a list of seven, including (i) content knowledge, (ii) general pedagogical knowledge, (iii) curriculum knowledge, (iv) pedagogical content knowledge, (v) knowledge of learners and their

Copyright (C) 2022 by Author/s and Licensed by Veritas Publications Ltd., UK. This is an open access article distributed under the Creative Commons Attribution License which permit unrestricted use, distribution, and reproduction in any medium, provided the original work is properly cited. 
characteristics, (vi) knowledge of classroom contexts, and (vii) knowledge of educational ends, purposes, values and their philosophical and historical grounds (Shulman, 1987, p.18).

A number of educators, building upon Shulman's conceptualizations above, have used different terms to describe the nature or type of knowledge a teacher needs to be able to teach, in addition to having subject matter knowledge. Some educators for instance refer to this kind of knowledge as the "teacher's personal knowledge" (Brown \& McIntyre, 1993; Connelly \& Clandinin, 1985; Pajares, 1992), the "teacher's personal practical knowledge" (Connelly \& Clandinin, 1985; Elbaz, 1981, 1983, 1991; Verloop et al., 2001), "teacher's professional craft knowledge" (Brown \& McIntyre, 1993; Shimahara, 1998), "teacher lore" (Schubert \& Ayers, 1992), "action oriented teacher knowledge" (Carter, 1990), and or the "teacher's context related knowledge" (Cochran, DeRuiter, \& King, 1993; Van Driel, Verloop, \& De Vos, 1998). Though different terms and facets are used, the educators agree that it is with this kind of knowledge and competences that the teacher is able to among other things, relate the subject matter with other field areas and everyday life experiences, identify and deal with students' learning difficulties and needs. Barnette \& Hodson (2001), for instance, categorize this knowledge into professional and classroom knowledge, and describe the teacher's professional knowledge as "the knowing of teaching by unconsciously reflected experience" (p. 438), and includes ideas, perspectives, insights, images of students, teachers and teaching, what is working and not, what teachers know, do and feel. The authors also describe classroom knowledge as another element of the teacher's knowledge with which the teacher is able to "think on their feet" at both a micro and a macro level, "observe their students and constantly adjust their tone, delivery, activities, verbal interactions, and so on, to ensure that the lesson proceeds as intended" (Barnett \& Hodson, 2001, pp. 438-439). Milner-Bolotin (2019, 2020) adds to this teacher's knowledge, the teacher's ability to embrace and use modern technologies to solve teaching problems.

As one of their main responsibilities, teacher educators must ensure that their trainees (pre-service teachers) acquire and develop the different teacher knowledge elements and competences as will be needed in real teaching situations. Indeed, the need for teacher educators to identify strategies and authentic platforms for prospective teachers to develop their teaching knowledge is one of the major recommendations appearing in recent studies on teacher knowledge (e.g.; Mikeska, Brockway, Ciofalo, Jin, \& Ritter, 2021; Subramaniam, 2021). However, equally important to recognize also is that, teacher educators cannot fully support their pre-service teachers' development of teacher knowledge unless they themselves have a good understanding of what constitutes this knowledge, how teachers learn, as well as what contextual conditions are needed to support the attainment of this knowledge (Kind, 2009b; Vail Lowery, 2002). Moreover, unlike the specialist subject knowledge (subject matter and educational theory), other teacher knowledge elements are tacit, hidden, and contextually bound (Carter, 1993; Kind, 2009b; Loughran et al., 2008), and thus not easy for educators to communicate and make visible to their pre-service teachers. Further still, several research reports over the years, have also indicated that not all teacher knowledge elements can be attained from the classroom teaching that goes on in teacher education (e.g.; Ball \& Cohen, 1999; Barnett \& Hodson, 2001; Berry, Depaepe, \& van Driel, 2016; Hiebert, Morris, Berk, \& Jansen, 2007; Kleickmann et al., 2013). For instance, Barnett \& Hodson (2001), when characterizing what constitutes the teachers' professional and classroom knowledge, argue that these two teacher knowledge elements are largely developed in and with practice. With this understanding, it implies that teacher educators should not only focus on teaching theoretical components of teacher knowledge as indicated in several research reports (see; Abell et al., 2009; König et al., 2020; Loughran et al., 2008; Ünver, 2014), but they should also endeavor to find and include feasible strategies to support their students (pre-service teachers) in developing a set of teacher knowledge elements understood to be acquired in and with practice.

\section{How Could Teacher Educators Support Pre-Service Teachers' Development of Professional and} Classroom Knowledge?

As described in the previous section, the teacher's professional and classroom knowledge constitutes a set of teacher knowledge and competences that are largely attained in and with practice or through interaction with the school system (setting). That said, teacher educators are still expected to contribute to pre-service teachers' development of this teacher knowledge component. A few research studies on teacher knowledge have come up with some suggestions that could be helpful to teacher educators in their effort to find feasible ways to support their pre-service teachers in developing this component of teacher knowledge. Examples of these include among others, Subramaniam (2021) who suggests the need to provide authentic platforms for pre-service teachers to trace and track their teacher knowledge development during methods courses and Hiebert et al. (2007) who propose a framework for teacher preparation programs aimed at helping prospective teachers to learn how to teach from studying teaching. Hiebert et al.'s (2007) framework comprises four skills, setting learning goals for students, assessing the achievement of goals, developing hypothesis for why the lesson work well or why it did not, and then revising the lesson based on the developed hypothesis. 
While the above suggestions and more of them are presented in educational literature, very few studies, offer clear methodological roadmaps regarding how to operationalize the proposed suggestions and frameworks in real practice. This has left a number of good ideas unused, since it is difficult for the teacher educators to work out feasible strategies to operationalize the ideas suggested in literature. Moreover, with teacher educators increasingly engaged in both research and teaching, it implies limited opportunities for them to experience what is going on in schools where prospective teachers will be working after training. Teacher educators most likely encounter real school teaching situations when they visit their pre-service teachers in practicum. Consequently, there is little room for teacher educators to contribute or otherwise oversee the development of teacher knowledge elements that are conceived as largely acquired during and with practice in actual teaching situations. Consequently, strategies that could be considered effective and feasible for teacher educators to work with, would be those that are easily integrated into the teacher educators' teaching structure, which currently is a blend of teaching and research, coupled with a few rounds of school visits, often when trainees are carrying out their practice.

In this study, one such strategy, considered to potentially lead to teacher knowledge development is explored. This strategy which has been previously recommended by a number of scholars (e.g.; Brouwer \& Korthagen, 2005; Friedrichsen et al., 2009; Kleickmann et al., 2013; Lee, Brown, Luft, \& Roehrig, 2007; Park \& Oliver, 2008), involves combining pre-service teachers' school practice (teaching experiences) with a reflection process. Several research reports indicate that through reflective practicing, which according to Schön (1983, 1987), could be reflection-in-action (practice of reflection in real-time during the activity) or reflectionon-action (reflection after the activity), practitioners get to understand better what they know and do and hence develop their knowledge through practice. It is a way to examine practice, discover gaps and do research to find new solutions. It is a lens with which lived-teacher experiences are experienced (eg; Abell et al., 2009; Brookfield, 1995; Catalana, 2020; Corrigan, 2009; Geng, Smith, Black, Budd, \& Disney, 2019; Hagevik, Aydeniz, \& Rowell, 2012; Killen, 2006; Schön, 1983, 1987; Sellars, 2012; Slade, Burnham, Catalana, \& Waters, 2019; Smyth, 1992). However, despite the strong support for the potential of reflective practice in supporting teacher knowledge development when tied with real teaching experiences, research studies that clearly show teacher educators how teacher knowledge development could be supported through a combination of teaching experiences and reflection are hardly found in educational literature.

One study that provides some insights into how reflective practice could support pre-service teachers' development of what he called "professional knowledge" is by Loughran (2002). Loughran notes that there are two possibilities that can be exploited by teacher educators in supporting pre-service teachers' learning through experience. The first and traditional way is for teacher educators to extract learning experiences from preservice teachers, who through debriefs in small groups are asked to talk about and share their practicum experiences. Accordingly, the educator extracts and filters these shared experiences and challenges and develops knowledge elements and then proceeds to offer insights to students regarding teaching aspects that they had not recognized previously. The author notes however that the support that comes from these exchanges does not yield in much learning. Most often, outcomes of such discussions are limited to pre-service teachers obtaining an awareness of the commonality of teaching problems, challenges and dilemmas, and that these common issues are resolvable, as well as getting to appreciate how difficult the transition from student to teacher is.

The second possibility is when pre-service teachers, after or during their practicum are asked to "develop assertions about their practice" (p. 38). Here pre-service teachers have an opportunity to analyze and make sense of their teaching experiences and could even go further and document and share their assertions with others. These two possibilities present two different processes through which the teacher educator could support development of teacher knowledge during and after school practice. Loughran (2002) argues that it is important to pay attention to the process of developing this knowledge and the question of who does the learning. With the second option, the pre-service teacher actively takes part in the construction of the learning. This second option according to Loughran (2002) provides for effective reflective practice, where there is ownership of teaching assertions, development of assertions, where the pre-service teacher recognizes and articulates a knowledge about practice and hence a transition in thinking.

By considering Loughran's (2002) conceptions above, a combination of teaching practice and reflection is possible and with a carefully planned methodological framework, teacher educators could be able to provide a supportive process that allows pre-service teachers to analyze their own practice, make and document their own teaching assertions. This would however demand that teacher educators are able to design activities to operationalize reflective practice, and to capture the results of the reflection. As earlier expressed by Collin, Karsenti, and Komis (2013), reflective practice or its development cannot be directly observed during teacher training, rather it is manifest in actions (e.g., adapting teaching practices considering teaching situations during the practicum) and discourse (talking and writing about teaching practices). Moreover, Collin et al. (2013) 
further express that manifestations of reflective practice are unsystematic, unshaped fragments that show evidence of reflective practice. For example, in a training program reflective practice usually manifest when students are provided with support tools for reflective practice. These tools could be pedagogical tools (e.g., portfolio, discussion groups) for assessing reflective practice and its development for educational purposes, or methodological tools (e.g., individual and group interviews, classroom observation) for examining reflective practice and its development for scientific purposes. Consequently, a combination of teaching experiences and reflection demands that the teacher educator is able to design activities to trigger the reflection process and as well as having the ability to facilitate a reflection process that results in pre-service teachers' development of teaching perspectives.

\section{The Goal of the Present Study}

The present study contributes to educational research efforts aimed at providing feasible strategies to support pre-service teachers' development of teacher knowledge. Focus is put on a component of the teacher's knowledge known to be largely acquired in practice (real teaching situations), that is, the teacher' professional and classroom knowledge. The study's aim was to explore the potential of reflective practice as a tool that could be used by teacher educators in supporting pre-service teachers' development of professional and classroom knowledge elements. This aim was underpinned by the understanding that pre-service teacher trainees can develop their teacher knowledge through a combination of real teaching and reflection. Moreover, it is possible and plausible for teacher educators to directly contribute to pre-service teachers' development of professional and classroom knowledge elements that are considered largely developed in and with practice, given that teacher educators have a direct influence on the trainees' school practice. Having influence on school practice also implies the possibility for teacher educators to be able to arrange school practice along with reflection activities. Consequently, through a carefully planned methodological design, this study sought to establish whether documenting lived teaching classroom experiences as a form of reflective practicing (reflective writing), was an effective way to support pre-service teachers' development of pre-service teacher trainees' professional and classroom knowledge.

\section{METHODOLOGY}

This research employed a descriptive case study approach (Creswell, 2002; Merriam, 2002; Yin, 2009) to explore how the process of reflective practicing, and as well as documenting one's lived-teaching experiences, could result in development of professional and classroom knowledge of two pre-service chemistry teachers. The study's methodological design was anchored on the practice of reflecting in and on one's practice or lived experiences within a specific context (Schön, 1983, 1987), and as well as the ability to document and communicate these reflections to a target audience. Since the goal of the study was to explore the potential of reflective practice in mediating development of teacher knowledge (professional and classroom knowledge), there was the need to establish which participant actions, results or behavior would serve as indicators of the sought development. Based on Loughran's conceptual understandings regarding effective reflective practice, it was anticipated that the reflective practice process and through the course of documenting reflections and meta-reflections, would result in pre-service teachers developing personal theories and assertions about their teaching experiences (Loughran, 2002). Consequently, the nature of the developed personal theories or own assertions resulting from the reflective practice process could serve as an indicator of a transition in the preservice teacher's thinking and hence a move towards professional and classroom knowledge development. Moreover, a descriptive case study approach was chosen to allow for a concise account of how the participants described their lived teaching experiences to be given, and as well as a researcher's commentary on what the given accounts could imply in relation to the research question of interest.

\section{Research Setting and Process Setting}

The study took place during the 16 -weeks autumn semester running from August through December 2019 at a teacher education institute in Norway. Study subjects were pre-service (secondary) teacher trainees with chemistry as one of their teaching subjects in their final year of teacher education training. The autumn semester at this teacher education institute is organized such that, pre-service teachers start their studies at teacher education for about 5 weeks before going to schools for their practicum, where they spend about 6 weeks. After practicum, pre-service teachers return to the teacher education institute for another 5 weeks of study before the semester ends. During this 16-weeks long semester, these two pre-service teachers took part in a chemistry didactic course that followed the above-described semester structure. The research activities for this study were planned, aligned with, and executed alongside the teaching of this didactic course, and as well organized to suit in the school practicum timeframe. While 21 science pre-service teacher trainees took part in the chemistry didactics course during the 2019 autumn semester, only two pre-service chemistry teacher trainees were involved in this study. The selection of these two participants was based on the participants' willingness to follow and thereby complete all the activities as planned and described in the research procedure. Since this appeared 
to be an additional work for most pre-service teachers, only these two offered to take part in the study. Moreover, despite that the case study methodology implied no possibility for generalizations, data from the two participants would provide the needed insights and understandings regarding the use of reflective practice as a mediation tool for teacher knowledge development.

\section{Research Process}

\section{The Research Process Comprised Three Steps}

Step1: Before school practice: The first step was when the two-participant chemistry pre-service teachers who accepted to take part in the study were at the teacher training institute together with other trainees before going into their school practice. While at the institute, these pre-service teachers obtained an orientation into the different teacher knowledge elements as described in the introduction section. In addition, they also learnt about reflective practice and how this could be implemented during their school practice period, with a specific focus on talking and writing about own teaching experiences as a form of operationalizing reflective practice. Following this, it was planned, and the two participant pre-service teachers agreed to the request to document their teaching lived experiences for at least one of the lessons that they were to conduct during school practice. Accordingly, while on school practice, each participant was to select a specific lesson and a time where it was also possible for the supervisor (educator) to attend, observe and make parallel notes for discussion. This would ensure a meaningful discussion between the pre-service teacher and educator, given that the educator would have access to his own reference notes for a productive discussion. Moreover, the educator would use these reference notes also during the analysis of the respective participants' documented reflective practice reports.

Step 2: During school practice. The second step took place during school practice. As had been agreed upon in step 1, the two pre-service teachers each taught their individual selected lessons with the teacher educators taking part as an observer. It was emphasized to the participants, to carefully consider both reflections in and on action when documenting their teaching experiences. After the lesson, the respective pre-service teacher and teacher educator held a brief one to one discussion about the observed/taught lesson. To avoid biasing or influencing the pre-service teacher's reflection process, the discussion was limited to majorly strengthening the working relationship between the educator and preservice teacher. It was agreed that any discussions about the lesson would take place after the pre-service teacher had submitted a reflective practice report for the observed lesson.

Step 3: Legitimization of teaching assertions. Step three was conceived as a teaching knowledge legitimization step, where pre-service teachers' developed assertions and perspectives are interrogated and legitimized in view of theoretical perspectives about teaching and learning. The process was achieved through discussions between the teacher educator and participants after the individual reflective practice reports had been submitted and studied. In addition to discussing the outcomes of the individual reports, participants were invited to respond to the following open-ended question.

"Before your school practice, you had an orientation into mainly two kinds of teacher knowledge conceptions, that is, pedagogical content knowledge (PCK), and subject content knowledge (CK).

a. Have you been able to use some of the ideas from these two kinds of knowledge to solve teaching problems that you have encountered during teaching? OR are there some issues or challenges that you encountered that needed another type of knowledge or skills different from these two above? Could you write your experiences about this?

b. If it so happens that these above two knowledge kinds were insufficient for solving certain classroom issues or teaching problems that you encountered, could you please briefly explain the kind of knowledge or skills you used to deal with the problems?"

This open-ended question was meant for pre-service teachers to evaluate the general usefulness or application of the knowledge about teaching obtained during teacher training before school practice.

\section{Analysis}

The individual pre-service teachers' reports documenting their lived teaching experiences during school practice and the individual written responses to the open-ended question, were the main sources of data for the present study. These were supplemented by notes taken by the educator during individual lesson observations. The focus for analysis was to identify indicators of teacher knowledge development as reflected in the participants' documented teaching experiences. As already pointed out at the start of the methodology section, the pre-service teachers' personal assertions about teaching, emerging from their respective teaching experiences, would represent a transition in their thinking about the teaching process. These assertions and hence the identifiable transitions in thinking from the reflection process would serve to indicate whether or not, reflective practice potentially supports the participants in developing new perspectives regarding the way they conceptualize the teaching process. Consequently, the goal of the analysis was to identify the participants' developed assertions and emerging perspectives from the documented teaching experiences as indicators of transitions in the 
participants' thinking about the teaching practice. Three questions which informed the analysis process include.

1. What did the two pre-service teachers write about their teaching experiences?

2. What perspectives emerge from the pre-service teachers' written reports and the discussions held between the pre-service teachers and the teacher educator?

3. How did pre-service teachers experience the application or usefulness of the teaching knowledge obtained during the chemistry didactics course at the teacher education institute?

Data from the two participants were interpretively analyzed. This is well in line with a descriptive case study methodology(Creswell, 2002; Merriam, 2002; Yin, 2009), as the researcher's interpretive layer would enable the study's target audience to understand the plausible connections between the participants" views and the underlying theories within the teaching framework. Focus during the analysis was put on identifying the taken-for granted assumptions about particular teaching situations, challenging teaching episodes and moments, changes in perspectives, justifications and rationales for specific moments of practice, as well as emerging individual pre-service teachers' assertions about the practice. Inferences from the analysis of individual pre-service teachers' reflective practice reports were compared with the respective preservice teacher's responses with the open-ended question, and as well as with notes taken by the educator during the individual lesson observations. This was done to map out both the coherency and consistency in the individual participant's perceptions and or otherwise the transitions in thinking about the practice of teaching.

\section{RESULTS AND DISCUSSION}

The findings of the present study are presented and discussed in the form of responses to three questions; (i) What did the pre-service teachers in this study write about their teaching experiences in the respective reflective practice reports? (ii) What perspectives emerge from the pre-service teachers' written reports and the discussions held between the pre-service teachers and the teacher educator? and (iii) How did pre-service teachers experience the application or usefulness of the teaching knowledge obtained during the chemistry didactics course at the teacher education institute?

What Did the Two Pre-Service Teachers in This Study Write About Their Teaching Experiences in The Respective Reflective Practice Reports?

By studying and making sense of both participants' reflective reports, the writing structure for both participants (pre-service teachers) hinged on the following seven aspects considered to characterize the individual's teaching context; (i) a description of the context of the lesson, (ii) lesson content aims and goals, (iii) students' background knowledge, behavior and expectations thereof, (iv) lesson instructional organization, planned activities and lesson sequence, (v) minute by minute lesson development and propagation, (vi) students' unfolding behavior, influenced by teacherbehavior and or vice versa, and (vii) lesson termination evaluation of attainment of lesson aims. Based on this structure, the pre-service teachers then identified challenging episodes that they respectively conceived or implied to have encountered at certain stages of the lesson development from the start through the end. The reflective reports were concluded by a reflective summary where the individual participants made propositions about the plausible solutions to the identified challenging episodes.

An example from one of the participants illustrating the above writing structure, including the identified challenging episodes is shown in Table 1 .

Considering the text sample from Sharon's report (Table 1), the text unfolding as well as its genre indicates that Sharon is working within a framework that seems to inform the step by step writing process, including which aspects to consider from the start to the end. The participants' writing thus displayed an inherent set of cognitions and beliefs that informs how the pre-service teacher conceived the teaching process, and how teaching activities are structured and sequenced, as well as what underlying factors require attention during the teaching learning process. Some scholars have described this set of cognitions and beliefs as the teachers' interpretive framework, that informs his/her way of teaching, meanings attached to teaching situations, as well as his/her decisions and actions (Kelchtermans, 1993, 2009; Vanassche \& Kelchtermans, 2014). The structured unfolding of teaching episodes portrayed in the participants' writings as exemplified in Table 1, appeared characteristic of a teaching framework learned in teacher education, thereby reflecting the participants' pedagogical content knowledge competences. That is, knowledge about planning, structuring \& sequencing the lesson, having an awareness of students, defining lesson goals and objectives, etc (Barnett \& Hodson, 2001; Hiebert et al., 2007).

The analysis revealed that working within the abovedescribed framework enabled participants to make sense of their teaching, keeping track of the unfolding of the activities, while drawing on an already pre-planned teaching structure and sequence. Consequently, it can be inferred from the analysis that the participants' reflection process which was majorly a "reflection-on- action" (Schön, 1983, 1987), was underpinned and hence based on their inherent interpretive framework (an accumulated set of cognitions and beliefs about teaching), by which they identified challenging episodes and made propositions for changes in the future teaching. 
Table 1. The case of Sharon - (pseudonym): excerpt showing the writing foci

\begin{tabular}{|c|c|c|}
\hline Writing focus & Text sample from Sharon's report & Identified challenging episodes \\
\hline $\begin{array}{l}\text { *Nature of students - } \\
\text { background } \\
\text { knowledge }\end{array}$ & $\begin{array}{l}\text { "During this school practice in the fall of } 2019 \text {, I have taught } \\
\text { natural sciences in first year upper secondary school for } \\
\text { students taking construction/building. This class consisted } \\
\text { of boys only with generally a low motivation for learning } \\
\text { science. .... }\end{array}$ & $\begin{array}{l}\text { *Awareness of students low } \\
\text { motivation }\end{array}$ \\
\hline $\begin{array}{l}\text { *Lesson content; aims } \\
\text { and goals. }\end{array}$ & $\begin{array}{l}\text { The overall theme was Nutrition and Health for the lesson } \\
\text { in question. The class had previously learned about the } \\
\text { various nutrients and therefore the first hour was dedicated }\end{array}$ & $\begin{array}{l}\text { * Students inactive during the first } \\
\text { session }\end{array}$ \\
\hline $\begin{array}{l}\text { *Lesson instructional } \\
\text { organization, planned } \\
\text { activities and sequence }\end{array}$ & $\begin{array}{l}\text { for a review of the digestive system. However, some of the } \\
\text { students felt that this was very theoretical and that it was } \\
\text { demanding to for them to sit still and watch the whole hour. } \\
\text { I had promised them that the next hour should not be as } \\
\text { theoretical, and that it should have elements of practical } \\
\text { work. The first hour started with drawing the digestive } \\
\text { system on the board without naming it. I had printed some } \\
\text { sheets of names of the parts of the digestive system along }\end{array}$ & $\begin{array}{l}\text { *Students feel it's demanding to sit } \\
\text { and watch inactively }\end{array}$ \\
\hline $\begin{array}{l}* \text { Unfolding } \\
\text { teacher/student } \\
\text { behavior, actions, and } \\
\text { reactions }\end{array}$ & $\begin{array}{l}\text { with the functions of the different parts of the system. The } \\
\text { students were given the task of attaching the sheets to the } \\
\text { blackboard at the correct part of the drawn digestive system. } \\
\text { This became an easy activity for many students, but the } \\
\text { process resulted in high noise levels especially with one } \\
\text { student with ADHD (attention deficit hyperactivity } \\
\text { disorder) was very active. ...." }\end{array}$ & $\begin{array}{l}\text { * Nature of task good but the way it } \\
\text { was planned resulted in classroom } \\
\text { disorder -high noise lessons }\end{array}$ \\
\hline
\end{tabular}

As an example, in Table 1, Sharon planned a theoretical session during the first hour where students did not have an active role. Having gone through the session, she realized that it was heavy for students who simply listened, something which also seemed to negatively impact students' motivation. She thus in her evaluation commentary (not shown in table 1 due to space limitations) expresses that the theoretical session is relevant and should be maintained though with some changes including cutting it short.

"I would still have to start with a repetition of nutrients and the digestive system, placing emphasis on various carbohydrates and how they are digested and absorbed in the body. This background is needed if students are to be actively engaged in the session that follows. It is for students to have fresh in memory the theoretical substance that they will explore in the experiment. However, too much theoretical material may be much for several students and focusing on a few relevant aspects can help make the amount of information digestible."

The pre-service teacher's argument of maintaining a similar sequence of starting with the theoretical concepts, whereas makes a lot of sense, also considering the pre-service teacher's rationale for the structure, it portrays her as confined within a pre-conceived working framework structure that is believed to be the only way that leads to intended learning outcomes. Moreover, she suggests cutting down on the amount of content as the only way to deal with the students' inactivity that comes with the long theory session stretch. It is therefore reasonable to conclude here that the pre-service teacher was careful not to delve herself into the unknown (outside the working framework) by exploring other ways through which students could acquire the needed theory knowledge for active participation.

What Perspectives Emerge From the Pre-Service Teachers' Written Reports and the Discussions Held Between the Pre-Service Teachers and The Teacher Educator?

As already indirectly revealed in the previous section, the individual pre-service teachers' reflective practice reports were majorly limited to a description of the teaching structure, the unfolding of teaching activities as well as identifying problematic teaching episodes and how to deal with these. It was difficult to visualize or identify transitions in the pre-service teachers' thinking about the teaching practice reading the written reports. This is because they only provided general reflections about their teaching, carefully following a logical structure, and limiting themselves to only pointing out general classroom problematic issues. Moreover, in identifying problematic situations, the pre-service teachers appeared to pay little attention to science teaching practices or science content related problems. It was rather more on general pedagogical issues related to lesson structure, management of teaching activities and dealing with students' actions and behavior. 
Nevertheless, the analysis revealed some important assertions put forward by the respective pre-service teachers, which to some extent could be linked with their progressive teaching practice development.

\section{Some Examples of the Teaching Assertions Made by} the Participants

Some of the identified assertions relate to the science teaching practice or science content while others reflect a more general understanding of the teaching learning system and how the components of this system relate to one another. The two-science teaching related assertions identified from Sharon's accounts include.

\section{a. The need for a content knowledge base for an active} role in the learning process. As we have already seen in the previous section, sharon used a full hour for the theoretical session where her students played an inactive role. She documented in her report that "this was very theoretical and that it was demanding for them to sit still and watch the whole hour". Sharon promised to do things a little different next time. However, the pre-service teacher maintained that starting with the theoretical part was important and that she would approach the teaching in a similar way even the next time she would teach. According to this pre-service teacher, students need to understand the theory as a basis for participation in the learning process. That is; "the theory is needed for students to actively engage in other experimental parts of the lesson".

While this pre-service teacher's understanding has been in the previous section considered characteristic of a teacher working within a pre-determined teaching framework/structure, it could as well be considered as the pre-service teachers' underlying implicit understanding of what constitutes the basis (a precondition) for students' participation in the learning process. Indeed, the argument advanced by Sharon as a justification for her practice, seem consistent with several research accounts concerning the central role of students' background knowledge (- comprising both prior and discipline-specific knowledge) in the teaching and learning process (e.g.; Ausubel, 1968; Kalyuga, 2007; van Riesen, Gijlers, Anjewierden, \& de Jong, 2018). For example, students with insufficient prior discipline-based knowledge, participating in inquiry learning reportedly use less sophisticated strategies, and they need to perform several rounds of experiments before reaching conclusions when compared with those with more background discipline-specific knowledge (Hmelo, Nagarajan, \& Day, 2000; Schauble, Glaser, Raghavan, \& Reiner, 1991). Moreover, a positive correlation has been reported between students' prior knowledge and the ability to employ higher-order cognitive skills (Hailikari, Katajavuori, \& LindblomYlanne, 2008). That is, proponents of the cognitive load theory have argued that students' prior knowledge helps to decrease cognitive load and thereby leading to good learning performance (e.g.; Dong, Jong, \& King, 2020; van Riesen, Gijlers, Anjewierden, \& de Jong, 2019; Yeh et al., 2012). When it comes to practical work in science, science-related student pre-conceptions (background knowledge and experiences) are reported to exhibit a substantial impact on the possible learning from practical work (Hofstein, Navon, Kipnis, \& Mamlok-Naaman, 2005). Accordingly, students require a knowledge base a pool of personal theories that they can relate to as they construct and make sense on new information during practical work (Gunstone, 1991).

While the above alignment and positioning of Sharon's conceptualizations of the teaching practice within the existing research knowledge forms an important step in the mediation and reinforcement of Sharon's knowledge about teaching, other perspectives that seem to differ from Sharon's position must be also considered in the process of legitimizing the teacher's conceptions. For instance, proponents of experimental learning views (Dewey, 1916; Hoover \& Whitehead, 1975; Kolb \& Kolb, 2005) would consider Sharon's approach and justifications as denying students the opportunity to learn by doing. Moreover, there are some studies that investigated the potential effects of prior knowledge on students' learning (achievement), and whose results showed no, or only marginal positive effects associated with students having high prior knowledge (Hoz, Bowman, \& Kozminsky, 2001; van Riesen et al., 2018). Referring to the goal of the present study, here we see the opportunity for the teacher educator to take into context these different perspectives when discussing with Sharon, a way to provide Sharon with the opportunity to evaluate and to rethink her inherent personal theory about the teaching. This process is poised to trigger the needed transitions in the trainee's thinking about the teaching practice.

\section{b. A teaching activity, including experiments is mostly likely successful when students clearly understand what to do and why. Sharon conducted an experiment after the first full hour theoretical session whose parts are shown in Table 1. Unfortunately, the lesson did not go as she had planned as she writes in her report.}

"The experiment was meant to show that the enzyme amylase from saliva breaks down starch, so that starch is no longer being detected with the iodine solution. So, we had starch in form of flour, the iodine solution and then we had to spit into cups with flour to introduce the enzyme amylase. However, the experiment turned out to be a very demanding affair, there was a lot of noise, some used a lot of flour, some students did not pay attention at the beginning .... It all ended up with almost none of the groups getting the experiment right. Very few could explain what they were 
doing or what was the purpose of the whole experiment."

In reaction to this experience and during the one-to one discussion with the educator, Sharon expressed that the situation would be different if students had very well understood what they were being asked to do as well as the reasons behind all the processes.

"The teacher must be sure that students have understood the essence of the experiment or the procedure before they can perform the experimental activity. This increased understanding of what to do can also lower the number of questions the teacher receives about the experimental activity, so that more of the teacher's time can be used to facilitate and assess the attainment of learning outcomes of the activities"

Having spent a full hour teaching theory, Sharon went straight into the practical session with her students. The assumption was that students would be able to use the learned theorical concepts, to transfer the ideas, and follow the provided experimental procedure to complete the experiment successfully. However, as the experimental session commenced, Sharon realized that students could not make the anticipated knowledge transitions. Some managed to follow the procedure thereby adding saliva (enzyme) to the flour (Starch) but could not explain or justify their observations, while others simply played with the equipment. To Sharon, simply adding Saliva to flour and observing what happens was, but not the whole of the experiment's essence or purpose. Accordingly, students' conduct (behavior) during the experiment was indicative of a lack of knowledge about the underlying purpose of the experiment and what learning targets were aimed at by the experiment. In carrying out the experiment, Sharon wanted her students to gradually relate the observations at the macro level when the enzyme amylase was introduced to a sample of Starch, to the underlying processes occurring at the micro level as Starch was being hydrolyzed. By understanding the underlying processes occurring at the micro-level, which involve amylase breaking Starch into shorter polysaccharides, disaccharides, and then finally to monosaccharides, students would easily follow the observations at the macro level. Moreover, they would be able to explain their observations at any stage of the experimental process, regardless of whether there has been a complete hydrolyzation of Starch or not. Students would also be able to explore the other factors that have a role in the reaction, such as time. This is what Sharon implied by the statement; "understanding the purpose or essence of the experimental activity".

When the pre-service teachers' understandings above are analyzed with educational research on practical work in science classrooms in context, we find a myriad of studies (empirical and theoretical) emphasizing the importance of teachers making clear to their students what the goal or purpose of experiment is (see; Abrahams \& Millar, 2008; Gunstone, 1991; Hodson, 1990; Hofstein et al., 2005; Millar, 2010). In line with Sharon's arguments, several scholars have expressed that without a clear thought-out purpose, practical work in science is unproductive (Hodson, 1990), and at best, it only has a limited role in the learning process (Abrahams \& Millar, 2008; Osborne, 2015). In addition to teachers having a well thought-out purpose for practical work in advance (Hodson, 1990), scholars have also argued for students to be provided opportunities for interaction and reflection, including opportunities for metacognitive activities in addition to manipulating equipment and materials (Abrahams \& Millar, 2008; Gunstone, 1991; Tobin, 1990). In analyzing Sharon's assertion along with these arguments from research, we come closer to understanding what should entail a clear thought-out purpose for practical activities in science classrooms. Sharon's submission appeared to point to an understanding that considers the purpose or essence of the practical experiment to encompass the above elements as emphasized in literature. She seemed to have realized that the essence or purpose of the experiment is not realized until students are able to go beyond simply manipulating equipment and materials and start to relate their macro level activities to their inherent understandings at the micro level.

While this pre-service teacher's understanding represents a significant step in the knowledge development process, we shouldn't forget the paradigm shift in science education when it comes to practical work, where there is increasing emphasis on providing more degrees of freedom (Kolstø \& Knain, 2011). Consequently, the focus on making a relation between the observations at the macro level and what happens at the micro level should consider the possibility that, in experimental activities with more degrees of freedom, knowledge at the micro level may not be readily available to the students. The purpose of the experimental activity here therefore is to trigger students' reflections, thinking and explorations that would result in students developing new understandings. This consideration hence widens the working framework for practical work in science, a conception that Sharon seems not to consider in her expression of what should constitute the essence and or purpose of experimental activities.

\section{Assertions Reflecting General Pedagogical or Didactic Knowledge Competences \\ Some of the general assertions about teaching extracted from both Sharon' written reflective report and notes taken during the one-on one discussion include; (i) it is both cognitively and socially demanding to develop}


teaching lesson plans and making interesting and rich learning activities often involves strives, (ii) good ideas for teaching may work better in theory than in practice; (iii) prolonged teacher talks where students simply listen inactively do kill learners' interest regardless of their initial motivation levels, (iv) students learn more when their presence in class is both recognized and appreciated; (v) positive learning is associated with students being tasked to account for their individual roles; and (vi) conditioning students seems to solve management problems.

Most of these teaching assertions by Sharon (e.g., iii, iv, v, \& vi) are linked to the pre-service teacher's already existing teaching interpretive framework which as earlier said, informed the teacher's' conception of the teaching process. Thus, the assertions were simply a confirmation of the already inherent pre-service teachers' conceptual knowledge about teaching from teacher education and did not seem to be developing or emerging from the practice itself as new ideas. On the other hand, assertions (i) and (ii) appeared to emerge from the pre-service teacher's experience of teaching, that includes the planning and execution of teaching. First, the pre-service teacher admits having invested a lot both cognitively and socially to achieve what she considers as interesting and rich learning. Second is the realization of the difference between "knowing how to do it" theoretically and "doing $i t$ " practically. In other words, she realized that there is not a direct transfer of learned knowledge about teaching into the practical world of teaching without making necessary adjustments.

"Through the practice I have learned how demanding it is to make teaching lesson plans. I think everyone who wants to become a good teacher strives to add interesting and rich learning sessions for students. Unfortunately, I have experienced that, good ideas for teaching may work better in theory than in practice. It's a terrible discovery to have in the classroom, but nevertheless educational."

These two assertions appear to be an addition to the pre-service teachers' teaching knowledge framework and are poised to influence her perception about the practice of teaching in terms of the social and cognitive investments needed given that there are no static, ready or permanent tools or methodologies for effective teaching. Rather, it is a realization that effective teaching relies mostly on teacher's ability to plan, create, and implement a teaching that can be evaluated as meaningful or effective.

\section{The Case of Alex:}

Alex (the second pre-service teacher) also made several statements in both his written reflective report and during the discussions. These mostly reflected his underlying conception of the practice of teaching, and just like for Sharon's case, the statements/assertions strongly depicted an understanding of the organization of the teaching structure or system and its components, as well as an expectation of how the elements in the teaching system (e.g., teacher and students) should relate to one another for meaningful learning experiences. The analysis did not reveal any subject specific teaching assertions that were made by Alex other than those reflecting the general pedagogical knowledge competences.

Examples of Alex's teaching assertions included; (i) reviewing lesson objectives at the start provides the needed coherence and provides students with security about the consistence in what they learn, (ii) students are motivated for learning when they have ownership of the learning objectives; (iii) a highly motivated classroom is associated with and hence characterized by students-led activities and self-regulated learning; (iv) students work at different rates and the teacher's teaching should accommodate these differences; (v) maintaining a student-adapted but continuous assessment provides for students' continuity and bridges gaps between the different students' work rates, and (vi) in complex or unexpected teaching situations, the teacher's social skills are a vital tool.

Just like Sharon, Alex's assertion (vi) from the list above, also appeared to have emerged as a result of the pre-service teacher's teaching practice experience.

"On teaching, .... I feel I had more benefit from using social skills and compassion to face situations I did not expect. So, I suppose a combination of regular social skills and the "carrot and stick"-principle (though mostly carrot), works well in complex situations."

Alex's submission aligns very well with what Sharon considered to be a combination of both the cognitive and social investment to achieve a learning that is meaningful and interesting. It is a realization of the complexity of the teaching and learning process that both Alex and Sharon have come face to face during school practice. This realization is important in the development stages of the teaching career as an addition to the pre-service teachers'already existing teaching knowledge base and or their inherent teaching interpretive frames built during teacher education training.

How Did the Two Pre-Service Teachers Experience the Application or Usefulness of the Teaching Knowledge Obtained During the Chemistry Didactics Course At the Teacher Education Institute?

The results in this section were meant to shade light on whether the pre-service teachers were able to apply or otherwise visualize the usefulness of the learned concepts from the chemistry didactics course (and from 
the general pedagogical studies) they had before going into school practice. The two pre-service teachers had different views concerning their individual experiences regarding the usefulness and application of a teaching knowledge (pedagogical content knowledge and subject didactics) acquired during training at teacher education. First, Sharon on one hand appeared to be frustrated having realized a lack of a direct transfer or application of the teacher knowledge aspects from teacher education. In her evaluation, there was hardly anything tangible from pedagogy that she understood to have applied in her classroom, apart from using different teaching approaches that she learnt in chemistry didactics. Sharon maintained that it was the content knowledge that she needed most, and moreover, it was her social skills and compassion that were in play during challenging teaching situations.

\section{"I needed the subject content knowledge to a much greater extent than the educational knowledge. I hardly think I've learned anything so tangible that it could be applied in the classroom from general pedagogy. In chemistry didactics, we learned about different approaches, and that was perhaps the only useful thing I feel I have with me. I feel I have benefited more from using social skills and compassion to address situations that I didn't expect."}

Second, unlike Sharon, Alex felt that the pedagogical content knowledge was more useful in his teaching when compared to how much subject content knowledge was used. He adds that the level of his students was decisive regarding the structuring and sequencing of the lessons, including nature, scope, and level of content knowledge.

"This was a grade 8 science class (age 13 students), so pedagogical content knowledge was more vital than regular subject knowledge in my view. This was particularly because the knowledge gap between me and my pupils was so big. I had to consider what would be realistic learning goals for a class of pupils at that age with their previous knowledge and try to place myself in their situation to see how I could present the subject in a way that would make sense to them."

The two pre-service teachers' submissions show a variation in how they each conceptualize teacher knowledge from teacher education and its role in the teaching and learning process. Regarding Sharon's submission, there is no doubt to the fact that this preservice teacher benefited from the pedagogical knowledge ideas and strategies from teacher education, contrary to what she appears to claim. This was visible in the way she structured her reflective practice report as discussed in earlier sections. Moreover, her language genre during the discussions was characteristic of a person adopted into the teaching culture and its working framework. However, she maintains that she did not see the usefulness of teaching knowledge ideas and strategies from teacher education. Sharon's submission thus indicates that this pre-service teacher had initially perceived knowledge from teacher education as a model or a set of working/guiding scientific formulae that could be directly applied in teaching situations. Alex on the other hand appears to have conceptualized theory from teacher education as a source of inspiration, with relevant themes and perspectives explaining the different teaching aspects and dimensions. Consequently, Alex could both explicitly articulate and visualize the application of the pedagogical knowledge ideas from teacher education.

\section{Is Teacher Education Formal Training a Source of} Teacher Professional and Classroom Knowledge?

Although Sharon appeared to hold a wrong perception about the nature and application of teacher knowledge from teacher education, her case is not an isolated one. Earlier research reports have pointed out similar teachers' claims about the lack of a connection between teacher education studies and the reality faced in classroom and schools (e.g.; Abell et al., 2009; Flores, Santos, Fernandes, \& Pereira, 2014; Joram, 2007; Linda, Golez, Nagel, Nieto, \& Nieto, 2002; Loughran et al., 2008; Shkedi, 1996; Ünver, 2014). For instance, about two decades ago, Linda et al. (2002) concluded in their study that teacher graduates had an insufficient understanding of educational theories to be able to apply them in classroom practice, or otherwise they did not conceptualize the difference between a theory and an instructional strategy. However, what we see from Sharon is not a lack of understanding of educational theories, but perhaps the inability to visualize this knowledge in practice.

Moreover, both Alex and Sharon emphasized how more important their social skills and competence were during the teaching learning processes. Indeed, Sharon claimed that it was mostly her cognitive and social skills rather than educational knowledge that she employed during her teaching. In other words, what Sharon implied was that formal teacher training in its current form, is not a source for professional and classroom knowledge, a conclusion that has often appeared in several research reports from the early 2000s (e.g.; Ball \& Cohen, 1999; Barnett \& Hodson, 2001; Shkedi, 1996).

The ability to recognize and distinguish between professional/classroom knowledge and educational theory, and their respective contributions to the teaching complex is an important step in teacher professional development. Of the two participants in the present study, Alex seemed to have conceptualized this difference, particularly recognizing how educational theory or knowledge from formal training shaped and 
influenced his teaching approach, decisions, and actions. Sharon on the other hand did not make this recognition but was able to point to the insufficiency of educational knowledge in practical situations. These two out-ofpractice discoveries by pre-service teachers are important steps in supporting the pre-service teachers to understand the relationship between educational theory and professional/classroom knowledge, the characteristics and nature of each knowledge element, and as well as the function served by the respective teacher knowledge.

The Teacher Educator's Role in The Mediation of Profession and Classroom Knowledge Development The goal of the present study was to explore whether preservice teachers' development of professional and classroom knowledge could be mediated through a reflective practice process where pre-service teachers write and talk about their teaching experiences. What comes out clear from the results is that the process possesses the potential to lead pre-service teachers to develop the desired teacher knowledge elements. However, this cannot happen until there are opportunities provided for negotiating, reinforcing and or legitimizing the outcomes of such reflection process. Moreover, teacher educators need to support pre-service teachers to have a good understanding of the nature and function of a teacher knowledge obtained during formal training. Frustrations about the lack of applicability of this knowledge arise following the inherently wrong perceptions about this knowledge as a model or set of guidelines to lead the teaching process. Because of this incorrect understanding, pre-service teachers even fail to visualize how this educational knowledge has impacted on their underlying social skills and other personal abilities with which they claim to manage and deal with problematic teaching situations.

Whereas the reflection process generally allows one to identify gaps in their practice and take a step back to find working solutions (in real time -reflection-in action, or after the practice -reflection-on-action), the crucial aspect for pre-service teachers is for them to be able to develop perspectives and assertions about the practice. As Loughran (2002) expressed, the assertions developed by pre-service teachers are not necessarily new or generally acceptable for that matter, but derive from a direct link to personal practice experiences. They thus represent an unfolding development in thinking about the practice. In addition, the constructed assertions are an indicator that the pre-service teacher was waiting to subject to test, and hence verify his/her inherently exhibited pool of ideas, perceptions and knowledge assumptions about the teaching practice, all of which are gathered through interaction with the social and the academic environment. Therefore, pre-service teachers' assertions are an important outcome of the reflection process that sets on course the mediation of knowledge development.

Once pre-service teachers return from school practice, they, together with the teacher educator have an opportunity to work through the individual pre-service teachers' constructed assertions. Through these educator -pre-service teachers discussions involving a synthesis of personal assertions, acceptable ideas and new perspectives about teaching are legitimized (Loughran, 2002). I provided some examples of how this could be achieved when I discussed Sharon's two assertions related to science teaching (see section: "Some examples of teaching assertions made by participants"). The educator should have the ability to gather literature supporting and against the pre-service teacher's assertions and bring this literature into the discussion. When pre-service teacher's conceptions are considered along with how the teaching process is conceived or described in literature, this forms a profound basis for triggering the desired thinking transitions. Consequently, the mediation process requires that the educator him/herself has a good orientation into the current/contemporary research developments in science education, to be able to analyze and discuss the preservice teacher's developed assertions in light of the current research developments in teaching.

For the present study however, the writing focus by the participants was narrow, limited to observable events and tracking of the development of lesson. There was a lack of a deep reflection where connections between theory and practice are visible. Perhaps this was difficult for the pre-service teachers, since they did not receive supervision into what is expected. Consequently, the expectation that pre-service teachers would develop several teaching assertions and teaching perspectives did not emerge out as anticipated both from the written reflective practice reports as well as from the held discussions. Thus, groundwork is needed from teacher educators to facilitate the process by guiding pre-service teachers on what aspects to focus on during the reflection process that are linked with educational theory. Moreover, the whole process should be iterative for progressive and meaning results where transitions in thinking about the practice could be visible. This means that whenever possible, the process should start with preservice teachers who at least have two cycles of school practice, where participants could revisit their initial teaching assertions and compare with those developed in cycle two of their school practice.

In view of the above, it should be noted that it was not possible for the teacher educator in this present study to conduct discussion sessions after the school practice period. There was therefore no opportunity for negotiating and legitimizing pre-service teachers' developed assertions. The reason for this was because the participants in the present study were in their final year of their teacher education training which ended shortly 
after school practice. However, due to the importance attached to teachers developing a knowledge base for teaching, a similar study involving more school practice cycles is ongoing. With two or more school practice cycles, the exploration of pre-service teachers' transitions in thinking about the teaching practice as well as the changes in their initial developed teaching assertions would be possible.

\section{Other Considerations and Study Limitations}

As presented in the literature review part, the reflection practice process is conceptualized as comprising a reflection-on-action and reflection-in action components. The latter, reflection-in-action, a process that one executes without being able to say what they are doing (Schön, 1987), is understood to be difficult. According to Schön (1987), when practitioners are invited to talk about what they do, "skillful improvisers often become tongue-tied or give obviously inadequate accounts" (p. 31). This challenge was clearly visible in the present study. The teacher educator observing the participants in actual teaching noted several instances of reflection-in-action, which none of the participants managed to capture in their reflective practice reports. While it is important for pre-service teachers to have a good understanding of the benefits of keeping track of the unfolding events of their own teaching before, during and after teaching, attention should be paid not to fall into the trap of concentrating on capturing real-time teaching events and forget the teaching itself. The teaching process relies mostly on what the teacher does and how s/he does it. The teacher must be ready to moderate the discussion, adjust the activities based on the changing context, including how students are reacting to classroom activities in real-time ( Kayima \& Jakobsen, 2020). Being the actor in action, it becomes difficult for the pre-service teacher to keep track of the reflection-in-action events. The pre-service teacher will thus be expected to give more weight to teaching, given that the ability to reflect-in-action, and at the same time take a step back to capture these rapidly changing classroom moments are to develop gradually and through a continuous practice.

Finally, this study while being qualitative, is majorly limited by having only two participants who took part in the study, and thereby impacting on the study's validity. Undoubtedly, this study would benefit from having more participants taking part in the project. In view of the aim of the study, the process through which individual preservice teachers develop teacher knowledge elements which are understood to be attainable in and with practice, cannot simply be generalized. This teacher knowledge development process is underpinned by several background factors unique to individual participants, among which are the variations in prior experiences, underlying beliefs and attitudes about learning, personal relation attributes, willingness to learn and re-learn from others. This means that each individual pre-service teacher might represent unique and interesting accounts, which when analyzed together with other participants, could yield rich and perhaps better and more informative analysis results. With only two participants, there are only two accounts to be analyzed and it will be difficult to tell whether the participants' underlying understandings are also shared by other preservice teachers.

However, the study becomes more relevant and meaningful to teacher education community when focus is put on the process of developing professional and classroom knowledge by pre-service teachers, and how teacher educators could support their pre-service teachers in this process. Once understood as described in the study, both the advanced suggestions as well as the tools for the reflection process are transferrable in other settings regardless of the number of pre-service teachers involved. This is the gist of the present paper. Moreover, the findings and discussions herein reinforce earlier research on using reflection practice to support preservice teachers to link educational theory and practice.

\section{REFERENCES}

Abell, S. K., Rogers, M. A. P., Hanuscin, D. L., Lee, M.

H., \& Gagnon, M. J. (2009). Preparing the next generation of science teacher educators: A model for developing PCK for teaching science teachers. Journal of Science Teacher Education, 20(1), 77-93. https://doi.org/10.1007/s10972-008-9115-6

Abrahams, I., \& Millar, R. (2008). Does practical work really work? A study of the effectiveness of practical work as a teaching and learning method in school science. International Journal of Science Education, 30(14), 1945-1969.

https://doi.org/10.1080/09500690701749305

Ausubel, D. P. (1968). Educational psychology: A cognitive view. New York, NY: Holt, Rinehart \& Winston.

Ball, D. L., \& Cohen, D. K. (1999). Developing practice, developing practitioners: Toward a practice-based theory of professional education. In G. Sykes \& L. Darling-Hammond (Eds.), Teaching as the learning profession: Handbook of policy and practice (Vol. 1, pp. 3-32). San Francisco: Jossey Bass.

Barnett, J., \& Hodson, D. (2001). Pedagogical context knowledge: Toward a fuller understanding of what good science teachers know. Science Education, 85(4), 426-453. https://doi.org/10.1002/sce.1017

Ben-Peretz, M. (2011). Teacher knowledge: What is it? How do we uncover it? What are its implications for schooling? Teaching and Teacher Education, 27(1), 39. https://doi.org/10.1016/j.tate.2010.07.015

Berry, A., Depaepe, F., \& van Driel, J. (2016). Pedagogical content knowledge in teacher education. In J. Loughran \& M. L. Hamilton (Eds.), International Handbook of Teacher Education (Vol. 1, pp. 347-386). Singapore: Springer Singapore. 
Brookfield, S. D. (1995). Becoming a critically reflective teacher (2 ed.). San Francisco: Jossey-Bass.

Brouwer, N., \& Korthagen, F. (2005). Can teacher education make a difference? American Educational Research Journal, 42(1), 153-224. https://doi.org/10.3102/00028312042001153

Brown, S. A., \& McIntyre, D. (1993). Making sense of teaching. Buckingham: Open University.

Bucat, R. (2005). Implications of chemistry education research for teaching practice: Pedagogical content knowledge as a way forward. Chemistry Education International, 6(1), 1-2.

Carter, K. (1990). Teachers' knowledge and learning to teach. In W. R. Houston (Ed.), Handbook of research on teacher education (Vol. 2, pp. 291-310). New York: MacMillan.

Carter, K. (1993). The place of story in the study of teaching and teacher education. Educational Researcher, 22(1), 5-12. https://doi.org/10.3102/0013189X022001005

Catalana, S. M. (2020). Indicators of impactful reflection in pre-service teachers: A case for creativity, honesty and unfamiliar experiences. International Journal for the Scholarship of Teaching and Learning, 14(1), 14.

Cochran, K. F., DeRuiter, J. A., \& King, R. A. (1993). Pedagogical content knowing: An integrative model for teacher preparation. Journal of Teacher Education, 44(4), 263-272.

Collin, S., Karsenti, T., \& Komis, V. (2013). Reflective practice in initial teacher training: Critiques and perspectives. Reflective Practice, 14(1), 104-117. https://doi.org/10.1080/14623943.2012.732935

Connelly, M. F., \& Clandinin, J. D. (1985). Personal practical knowledge and the modes of knowing: relevance for teaching and learning. In E. Eisner (Ed.), Learning and teaching the ways of knowing (Vol. 84, pp. 174-198). Chicago: University of Chicago Press.

Corrigan, D. (2009). Chemistry teacher education to promote understanding of learning through effective reflective practice. Chemistry Education Research and Practice, 10(2), 121-131. https://doi.org/10.1039/b908249m

Creswell, J. W. (2002). Educational research: Planning, conducting, and evaluating quantitative. New Jersey:: Upper Saddle River.

Dewey, J. (1916). Democracy and education: An introduction to the philosophy of education. New York, NY: Macmillan.

Dong, A., Jong, M. S.-Y., \& King, R. B. (2020). How does prior knowledge influence learning engagement? The mediating roles of cognitive load and helpseeking. Frontiers in Psychology, 11(2992). https://doi.org/10.3389/fpsyg.2020.591203

Elbaz, F. (1981). The teacher's "practical knowledge": Report of a case study. Curriculum Inquiry, 11(1), 4371. https://doi.org/10.2307/1179510

Elbaz, F. (1983). Teacher thinking: A study of practical knowledge. New York: Nichols.
Elbaz, F. (1991). Research on teacher's knowledge: The evolution of a discourse. Journal of Curriculum Studies, 23(1), 1-19.

Flores, M. A., Santos, P., Fernandes, S., \& Pereira, D. (2014). Pre-service teachers' views of their training: Key issues to sustain quality teacher education. Journal of Teacher Education for Sustainability, 16(2), 39-53. https://doi.org/10.2478/jtes-2014-0010

Friedrichsen, P. J., Abell, S. K., Pareja, E. M., Brown, P. L., Lankford, D. M., \& Volkmann, M. J. (2009). Does teaching experience matter? Examining biology teachers' prior knowledge for teaching in an alternative certification program. Journal of Research in Science Teaching, 46(4), 357-383. https://doi.org/10.1002/tea.20283

Geng, G., Smith, P., Black, P., Budd, Y., \& Disney, L. (2019). Reflective practice in teaching: Pre-service teachers and the lens of life experience(1st ed. 2019. ed.).

Grossman, P. L., \& Richert, A. E. (1988).

Unacknowledged knowledge growth: A re-examination of the effects of teacher education. Teaching and Teacher Education, 4(1), 53-62. https://doi.org/10.1016/0742-051X(88)90024-8

Gunstone, R. F. (1991). Reconstructing theory from practical experience. In B. Woolnough (Ed.), Practical science (pp. 67-77). Milton Keynes: Open University Press.

Hagevik, R., Aydeniz, M., \& Rowell, C. G. (2012). Using action research in middle level teacher education to evaluate and deepen reflective practice. Teaching and Teacher Education, 28(5), 675-684. https://doi.org/10.1016/j.tate.2012.02.006

Hailikari, T., Katajavuori, N., \& Lindblom-Ylanne, S. (2008). The relevance of prior knowledge in learning and instructional design. American Journal of Pharmaceutical Education, 72(5). https://doi.org/10.5688/aj7205113

Hiebert, J., Morris, A. K., Berk, D., \& Jansen, A. (2007). Preparing teachers to learn from teaching. Journal of Teacher Education, 58(1), 47-61. https://doi.org/10.1177/0022487106295726

Hmelo, C. E., Nagarajan, A., \& Day, R. S. (2000). Effects of high and low prior knowledge on construction of a joint problem space. The Journal of Experimental Education, 69(1), 36-56. https://doi.org/10.1080/00220970009600648

Hodson, D. (1990). A critical look at practical work in school science. School Science Review, 71(256), 33-40.

Hofstein, A., Navon, O., Kipnis, M., \& Mamlok-Naaman, R. (2005). Developing students' ability to ask more and better questions resulting from inquiry-type chemistry laboratories. Journal of Research in Science Teaching, 42(7), 791-806. https://doi.org/10.1002/tea.20072

Hoover, J. D., \& Whitehead, C. J. (1975). An experientialcognitive methodology in the first course in management: Some preliminary results. Paper presented at the Developments in Business Simulation and Experiential Learning: Proceedings of the Annual ABSEL Conference. 
Hoz, R. O. N., Bowman, D. A. N., \& Kozminsky, E. L. Y. (2001). The differential effects of prior knowledge on learning: A study of two consecutive courses in earth sciences. Instructional Science, 29(3), 187-211.

Retrieved from http://www.jstor.org/stable/41953549

Joram, E. (2007). Clashing epistemologies: Aspiring teachers', practicing teachers', and professors' beliefs about knowledge and research in education. Teaching and Teacher Education, 23(2), 123-135. https://doi.org/10.1016/j.tate.2006.04.032

Kalyuga, S. (2007). Expertise reversal effect and its implications for learner-tailored instruction. Educational Psychology Review, 19(4), 509-539. https://doi.org/10.1007/s10648-007-9054-3

Kayima, F., \& Jakobsen, A. (2020). Exploring the situational adequacy of teacher questions in science classrooms. Research in Science Education, 50(2), 437-467. https://doi.org/10.1007/s11165-018-9696-9

Kelchtermans, G. (1993). Getting the story, understanding the lives: From career stories to teachers' professional development. Teaching and Teacher Education, 9(5), 443-456. https://doi.org/10.1016/0742051X(93)90029-G

Kelchtermans, G. (2009). Who I am in how I teach is the message: Self-understanding, vulnerability and reflection. Teachers and Teaching, 15(2), 257-272. https://doi.org/10.1080/13540600902875332

Killen, R. (2006). Effective teaching strategies: Lessons from research and practice. Australia: Thomson Social Science Press.

Kind, V. (2009a). A conflict in your head: An exploration of trainee science teachers' subject matter knowledge development and its impact on teacher self-confidence. International Journal of Science Education, 31(11), 1529-1562. https://doi.org/10.1080/09500690802226062

Kind, V. (2009b). Pedagogical content knowledge in science education: Perspectives and potential for progress. Studies in Science Education, 45(2), 169-204. https://doi.org/10.1080/03057260903142285

Kleickmann, T., Richter, D., Kunter, M., Elsner, J., Besser, M., Krauss, S., \& Baumert, J. (2013). Teachers' content knowledge and pedagogical content knowledge: The role of structural differences in teacher education. Journal of Teacher Education, 64(1), 90106. https://doi.org/10.1177/0022487112460398

Kolb, A. Y., \& Kolb, D. A. (2005). Learning styles and learning spaces: Enhancing experiential learning in higher education. Academy of Management Learning \& Education, 4(2), 193-212. Retrieved from http://www.jstor.org/stable/40214287

Kolstø, S. D., \& Knain, E. (2011). Elever som forskere i naturfag. Oslo: Universitetsforlag.

König, J., Bremerich-Vos, A., Buchholtz, C., \& Glutsch, N. (2020). General pedagogical knowledge, pedagogical adaptivity in written lesson plans, and instructional practice among preservice teachers. Journal of Curriculum Studies, 52(6), 800-822. https://doi.org/10.1080/00220272.2020.1752804
Lederman, N. G., \& Lederman, J. S. (2015). The status of preservice science teacher education: A global perspective. Journal of Science Teacher Education, 26(1), 1-6. https://doi.org/10.1007/s10972-015-9422-7

Lee, E., Brown, M. N., Luft, J. A., \& Roehrig, G. H. (2007). Assessing beginning secondary science teachers' PCK: Pilot year results. School Science and Mathematics, 107(2), 52-60. https://doi.org/10.1111/j.1949-8594.2007.tb17768.x

Linda, W., Golez, F., Nagel, G., Nieto, C., \& Nieto, C. (2002). Listening to voices of practicing teachers to examine the effectiveness of a teacher education program. Action in Teacher Education, 23(4), 69-76. https://doi.org/10.1080/01626620.2002.10463090

Loughran, J., Mulhall, P., \& Berry, A. (2008). Exploring pedagogical content knowledge in science teacher education. International Journal of Science Education, 30(10), 1301-1320. https://doi.org/10.1080/09500690802187009

Loughran, J. J. (2002). Effective reflective practice: In search of meaning in learning about teaching. Journal of Teacher Education, 53(1), 33-43. https://doi.org/10.1177/0022487102053001004

Merriam, S. B. (2002). Introduction to qualitative research. In S. B. Merriam \& R. S. Grenier (Eds.), Qualitative research in practice: Examples for discussion and analysis (2 ed., pp. 1-17). Jossey-Bass: John Wiley \& Sons Inc.

Mikeska, J. N., Brockway, D., Ciofalo, J., Jin, H., \& Ritter, S. (2021). Examining variability in elementary science teachers' pedagogical content knowledge about phase change: Implications for teacher development and assessment. Journal of Science Teacher Education, $32(4), 400-424$. https://doi.org/10.1080/1046560X.2020.1831741

Millar, R. (2010). Practical work. In J. Osborne \& J. Dillon (Eds.), Good practice in science teaching: What research has to say (2 ed., pp. 108-134). New York: Open University press.

Milner-Bolotin, M. (2019). Technology as a catalyst for twenty-first-century STEM teacher education. In S. Yu, H. Niemi, \& J. Mason (Eds.), Shaping Future Schools with Digital Technology: An International Handbook (pp. 179-199). Singapore: Springer Singapore.

Milner-Bolotin, M. (2020). Deliberate pedagogical thinking with technology in STEM teacher education. In Y. Ben-David Kolikant, D. Martinovic, \& M. Milner-Bolotin (Eds.), STEM Teachers and Teaching in the Digital Era: Professional Expectations and Advancement in the 21st Century Schools (pp. 201219). Cham: Springer International Publishing.

Osborne, J. (2015). Practical work in science: Misunderstood and badly used? School Science Review, 96(357), 16-24.

Pajares, F. M. (1992). Teachers' beliefs and educational research: Cleaning up a messy construct. Review of Educational Research, 62(3), 307-332. https://doi.org/10.2307/1170741 
Park, S., \& Oliver, J. S. (2008). Revisiting the conceptualisation of pedagogical content knowledge (PCK): PCK as a conceptual tool to understand teachers as professionals. Research in Science Education, 38(3), 261-284. https://doi.org/10.1007/s11165-007-9049-6

Schauble, L., Glaser, R., Raghavan, K., \& Reiner, M. (1991). Causal models and experimentation strategies in scientific reasoning. Journal of the Learning Sciences, 1(2), 201-238. https://doi.org/10.1207/s15327809j1s0102_3

Schubert, W. H., \& Ayers, W. (1992). Teacher lore: Learning from our own experience. New York: Longman.

Schön, D. A. (1983). The reflective practioner. New York: Basic Books.

Schön, D. A. (1987). Educating the reflective practitioner. San Francisco, CA: Jossey-Bass.

Sellars, M. (2012). Teachers and change: The role of reflective practice. Procedia - Social and Behavioral Sciences, 55, 461-469. https://doi.org/10.1016/j.sbspro.2012.09.525

Shimahara, K. N. (1998). The Japanese model of professional development: Teaching as craft. Teaching and Teacher Education, 14(5), 451-462.

Shkedi, A. (1996). Teacher Education: What we can learn from experienced teachers. British Journal of InService Education, 22(1), 81-97. https://doi.org/10.1080/0305763960220108

Shulman, L. S. (1986). Those who understand: Knowledge growth in teaching. Educational researcher, 15(2), 414.

Shulman, L. S. (1987). Knowledge and teaching: Foundations of the new reform. Harvard Educational Review, 57(1), 1-23. https://doi.org/10.17763/haer.57.1.j463w79r56455411

Slade, M. L., Burnham, T. J., Catalana, S. M., \& Waters, T. (2019). The impact of reflective practice on teacher candidates' learning. International Journal for the Scholarship of Teaching and Learning, 13(2), 15.

Smyth, J. (1992). Teachers' work and the politics of reflection. American Educational Research Journal, 29(2), 267-300. https://doi.org/10.3102/00028312029002268

Subramaniam, K. (2021). Prospective teachers' pedagogical content knowledge development in an elementary science methods course. Journal of Science Teacher Education, 1-23. https://doi.org/10.1080/1046560X.2021.1939944

Tobin, K. (1990). Research on science laboratory activities: In pursuit of better questions and answers to improve learning. School science and mathematics, 90(5), 403-418.

Vail Lowery, N. (2002). Construction of teacher knowledge in context: Preparing elementary teachers to teach mathematics and science. School science and mathematics, 102(2), 68-83. https://doi.org/10.1111/j.1949-8594.2002.tb17896.x

Van Driel, J. H., Verloop, N., \& De Vos, W. (1998). Developing science teachers' pedagogical content knowledge. Journal of Research in Science Teaching, 35(6), 673-695.

van Riesen, S. A. N., Gijlers, H., Anjewierden, A., \& de Jong, T. (2018). The influence of prior knowledge on experiment design guidance in a science inquiry context. International Journal of Science Education, 40(11), 1327-1344. https://doi.org/10.1080/09500693.2018.1477263 van Riesen, S. A. N., Gijlers, H., Anjewierden, A. A., \& de Jong, T. (2019). The influence of prior knowledge on the effectiveness of guided experiment design. Interactive Learning Environments, 1-17. https://doi.org/10.1080/10494820.2019.1631193

Vanassche, E., \& Kelchtermans, G. (2014). Teacher educators' professionalism in practice: Positioning theory and personal interpretative framework. Teaching and Teacher Education, 44, 117-127. https://doi.org/10.1016/j.tate.2014.08.006

Verloop, N., Van Driel, J., \& Meijer, P. (2001). Teacher knowledge and the knowledge base of teaching. International Journal of Educational Research, 35(5), 441-461. https://doi.org/10.1016/S08830355(02)00003-4

Yeh, T.-K., Tseng, K.-Y., Cho, C.-W., Barufaldi, J. P., Lin, M.-S., \& Chang, C.-Y. (2012). Exploring the impact of prior knowledge and appropriate feedback on students' perceived cognitive load and learning outcomes: Animation-based earthquakes instruction. International Journal of Science Education, 34(10), 1555-1570. https://doi.org/10.1080/09500693.2011.579640

Yin, R. K. (2009). Case study research: Design and methods (Vol. 5). London: Los Angeles.

Ünver, G. (2014). Connecting theory and practice in teacher education: A case study. Educational Sciences: Theory and Practice, 14(4), 1402-1407. 